\title{
EMPATI
}

VOL. 8 N0. 1 JUNI 2019 | 82-91 | DOI: 10.15408/empati.v8i1.14690 p-ISSN: 2301-4261 | e-ISSN: 2621-6418

Website: http://journal.uinjkt.ac.id/index.php/empati

This is an open access article under CC-BY-SA license

(https://creativecommons.org/licenses/by-sa/4.0/)

\section{PENGARUH KUALITAS PELAYANAN PROGRAM PANGAN BERSUBSIDI TERHADAP KEPUASAN MASYARAKAT DI KELURAHAN PONDOK LABU JAKARTA SELATAN}

\author{
Puteri Nur Farrieda \\ LK3 UIN Syarif Hidayatullah Jakarta \\ Email: puterinurfariedanabila99@gmail.com
}

\begin{abstract}
The service of Subsidized Food Program is a program that has been set by the Government in 2017. The program aims to aid reducing the poverty and can also support increasing the nutritional intake for DKI Jakarta residents who are under the Poverty Line. Communities certainly want a service that is in line with their expectations in order to achieve their own satisfaction within the program and vice versa. This research is located in the Pondok Labu Subdistrict area of South Jakarta, in RPTRA Pinang Pola and RPTRA Pola Idaman because the region, specifically in South Jakarta, has total sales of Subsidized Food as many as 4238 food. The purpose of this study is to find out how much the quality of service affects community satisfaction. This study uses a quantitative approach with a sample of 100 respondents. For the technique of processing the data and statistical analysis uses IBM SPSS Statistics 22 software. The results of this study can be obtained based on the significance value of 0,000 where the number is smaller than the value of 0.05, which means that the service quality variable has a significant influence on the community satisfaction variable. As for based on the value of R Square (R2) of 59.6\%, which means that the service quality variable affects the community satisfaction variable while the remaining value of $40.4 \%$ is influenced or explained by other variables outside the research variable. This research is expected to be used as input for all parties to prioritize the quality of good service to produce good community satisfaction.
\end{abstract}

Keywords: The Service of Subsidized Food Program, Community Satisfaction.

Abstraks. Layanan Program Makanan Bersubsidi adalah program yang ditetapkan oleh Pemerintah pada tahun 2017. Program ini bertujuan untuk membantu mengurangi kemiskinan dan juga dapat mendukung peningkatan asupan gizi bagi penduduk DKI Jakarta yang berada di bawah Garis Kemiskinan. Masyarakat tentu menginginkan layanan yang sesuai dengan harapan mereka untuk mencapai kepuasan mereka sendiri dalam program dan sebaliknya. Penelitian ini berlokasi di wilayah Kecamatan Pondok Labu Jakarta Selatan, di RPTRA Pinang Pola dan RPTRA Pola Idaman karena wilayah tersebut, khususnya di Jakarta Selatan, memiliki total penjualan Makanan Bersubsidi sebanyak 4238 makanan. Tujuan dari penelitian ini adalah untuk mengetahui seberapa besar kualitas layanan mempengaruhi kepuasan masyarakat. Penelitian ini menggunakan pendekatan kuantitatif dengan sampel 100 responden. Untuk teknik pengolahan data dan analisis statistik menggunakan perangkat lunak IBM SPSS Statistics 22. Hasil penelitian ini dapat diperoleh berdasarkan nilai signifikansi 0,000 dimana angkanya lebih kecil dari nilai 0,05, yang berarti bahwa variabel kualitas layanan memiliki pengaruh yang signifikan terhadap variabel kepuasan masyarakat. Adapun berdasarkan nilai $R$ Square (R2) sebesar 59,6\%, yang berarti bahwa variabel kualitas layanan mempengaruhi variabel kepuasan masyarakat sedangkan nilai sisanya sebesar 40,4\% dipengaruhi atau dijelaskan oleh variabel lain di luar variabel penelitian. Penelitian ini diharapkan dapat digunakan sebagai masukan bagi semua pihak untuk memprioritaskan kualitas pelayanan yang baik untuk menghasilkan kepuasan masyarakatyang baik.

Kata kunci: Layanan Program Makanan Bersubsidi, Kepuasan Masyarakat. 


\section{Pendahuluan}

Salah satu problem utama manusia di dunia saat ini ialah tentang kemiskinan. Persoalan kemiskinan menjadi persoalan global. Kemiskinan layaknya penyakit sosial bagi suatu negara. Sebagaimana penyakit-penyakit sosial lainnya, maka keberadaan kemiskinan tentu saja menjadi persoalan. Hal ini tidak hanya dirasakan oleh satu negara melainkan persoalan global. Data terbaru dari Bank Dunia (World Bank) bahwa tingkat kemiskinan berkurang yakni berkurang sekitar 10 persen di tahun 2019 ketimbang tahun 2015 . Tetapi kita tidak boleh terburu-buru bergembira atas fakta itu. Bank Dunia juga mengingatkan bahaya yang lain bahwa laju pengurangan kemiskinan saat ini sedang melambat (Zuraya, 2018).

Supriatna (1997) menyebut kemiskinan sebagai situasi yang serba terbatas di mana hal tersebut terjadi bukan atas kehendak yang bersangkutan. Kemiskinan juga ditandai oleh beberapa hal: rendahnya tingkat pendidikan, rendahnya produktifitas kerja, rendahnya pendapatan, kesehatan, kurangnya gizi dan kesejahteraan. Semua itu menunjukkan lingkaran ketidakberadayaan.

Adapun beberapa dampak adanya kemiskinan yaitu banyaknya pengangguran yang disebabkan terbatasnya lapangan pekerjaan, kurangnya pendidikan, rendahnya kesehatan, krisisnya pangan dan keterbatasan modal untuk menciptakan pekerjaan. Dalam penelitian ini, diambilnya permasalahan dari salah satu faktor tersebut yaitu krisis pangan yang mana hal tersebut menjadikan sumber yang paling utama dari semua faktor yang disebutkan di atas (Hasim, 2015). Telah dipaparkan dalam Badan Pusat Statistik yang mana peneliti buat dalam bentuk grafik perkembangan penduduk miskin, yaitu sebagai berikut: 


\section{Pengaruh Kualitas Pelayanan Program Pangan Bersubsidi terhadap Kepuasan}

Masyarakat di Kelurahan Pondok Labu Jakarta Selatan

- Puteri Nur Farrieda

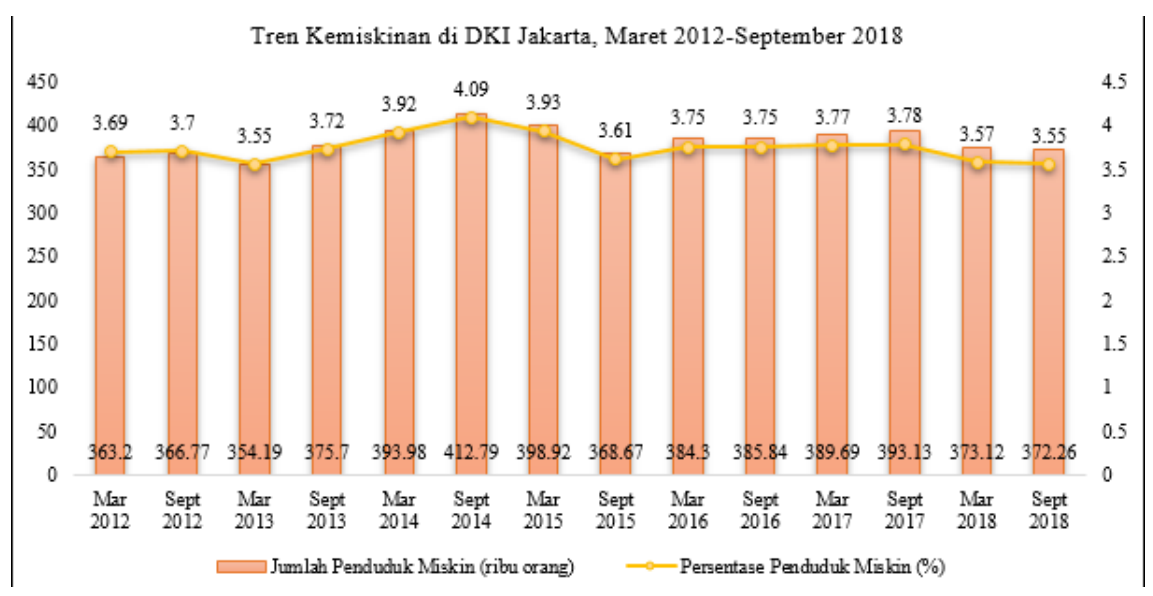

Gambar 1. Perkembangan Presentase Penduduk Miskin di DKI Jakarta, Bulan Maret 2013 - September 2018.

(Sumber: Badan Pusat Statistik, 2018).

Terlihat pada grafik di atas telah menjelaskan kemiskinan dan ketimpangan setiap tahunnya yang mana tingkat kemiskinan yang lebih parah pada tahun 2014 di bulan September, sangat berbeda jauh pada bulan Maret 2013 yang masih sangat rendah pada kemiskinan dan ketimpangan yang ada. Terdapat pula perubahan cuaca yang sangat ekstrem yang sedang terjadi di berbagai daerah, hal tersebut dapat mengakibatkan adanya krisis pangan. Seperti sering terjadinya hujan lebat ataupun kekeringan yang ekstrem dan mengalami dampak yang terus-menerus sehingga mengakibatkan pengolahan panen tidak mungkin dilakukan.

Berdasarkan keterangan di atas, peneliti sangat tertarik untuk meneliti suatu konsep yang membahas tentang Pengaruh Kualitas Pelayanan Program Pangan Bersubsidi Terhadap Kepuasan Masyarakat di Kelurahan Pondok Labu Jakarta Selatan karena tercatat sebanyak 7372 masyarakat yang berpendapatan rendah.

\section{Metode}

\section{Desain Penelitian}

Penelitian ini termasuk penelitian survei. Singarimbun (1991, h. 3) menyebut bahwa surevi adalah penelitian yang mengambil sampel dari satu populasi dan menggunakan kuesioner sebagai alat pengumpul data yang pokok". Penelitian survei merupakan kegiatan penelitian yang mengumpulkan data 
pada saat tertentu dengan dua tujuan tertentu yaitu mengetahui bagaimana kepuasan masyarakat dalam memperoleh pelayanan program pangan bersubsidi dan bagaimana kualitas pada program pangan bersubsidi yang diterima oleh masyarakat. Subyek dan tempat penelitian ini adalah masyarakat kelurahan pondok labu yang memiliki kartu jakarta pintar untuk bisa mendapatkan program pangan bersubsidi. Waktu penelitian dilakukan pada bulan Maret 2019.

\section{Populasi}

Dalam pengambilan sampel menggunakan teknik probability sampling yaitu lebih dikhususkan pada teknik random sampling. Teknik ini dilakukan secara acak atau dipilih secara acak, di mana setiap unsur pada populasi harus memiliki kesempatan yang sama agar bisa dipilih menjadi sampel. Terdapat 4238 masyarakat yang menggunakan kartu Jakarta Pintar tetapi peneliti hanya menggunakan 100 sampel untuk penelitian yang telah dihitung menggunakan rumus slovin.

\section{Teknik Pengumpulan Data dan Instrumen Penelitian}

Teknik pengumpulan data menggunakan metode kuesioner. Terdapat kisi-kisi yang digunakan sebagai dasar pembuat instrumen dalam penelitian ini adalah sebagai berikut:

\section{Tabel 1}

Kisi-kisi Instrumen Penelitian Reliability Kualitas Pelayanan

\begin{tabular}{|l|l|l|c|}
\hline \multicolumn{1}{|c|}{ Variabel } & \multicolumn{1}{|c|}{ Indikator } & No Item & Jumlah \\
\hline Reliability/ & $\begin{array}{l}\text { Ketepatan waktu dan tempat } \\
\text { Kehandalan }\end{array}$ & 1,3, & 5 \\
& $\begin{array}{l}\text { Ketepanan } \\
\text { pelayanan } \\
\text { Kecakapan dalam menanggapi } \\
\text { keluhan konsumen }\end{array}$ & 2 & \\
\hline
\end{tabular}


Tabel 2

Kisi-kisi Instrumen Penelitian Responsiveness Kualitas Pelayanan

\begin{tabular}{|l|l|l|c|}
\hline \multicolumn{1}{|c|}{ Variabel } & \multicolumn{1}{|c|}{ Indikator } & No Item & Jumlah \\
\hline $\begin{array}{l}\text { Responsiveness/ } \\
\text { Daya Tanggap }\end{array}$ & $\begin{array}{l}\text { - Kemampuan petugas dalam } \\
\text { menerima kritik dan saran dari } \\
\text { masyarakat }\end{array}$ & 7, & 5 \\
$\begin{array}{l}\text { Sikap tanggap dan kinerja petugas } \\
\text { dalam memberikan pelayanan } \\
\text { Pemerintah tanggap atas harapan } \\
\text { masyarakat }\end{array}$ & $8,9,10$, & \\
\hline
\end{tabular}

Tabel 3

Kisi-kisi Instrumen Penelitian Assurance Kualitas Pelayanan

\begin{tabular}{|l|l|l|c|}
\hline \multicolumn{1}{|c|}{ Variabel } & \multicolumn{1}{|c|}{ Indikator } & \multicolumn{1}{c|}{ No Item } & Jumlah \\
\hline $\begin{array}{l}\text { Assurance/ } \\
\text { Jaminan }\end{array}$ & $\begin{array}{l}\text { Petugas memberikan rasa yakin } \\
\text { dan aman kepada masyarakat } \\
\text { - Menciptakan rasa aman kepada } \\
\text { masyarakat dalam bertransaksi } \\
\text { - Kemampuan petugas bersikap baik } \\
\text { kepada masyarakat }\end{array}$ & 11,14, & 5 \\
& 15,12 & \\
\hline
\end{tabular}

Tabel 4

Kisi-kisi Instrumen Penelitian Empathy Kualitas Pelayanan

\begin{tabular}{|l|l|l|c|}
\hline \multicolumn{1}{|c|}{ Variabel } & \multicolumn{1}{|c|}{ Indikator } & No Item & Jumlah \\
\hline $\begin{array}{l}\text { Empathy/ } \\
\text { Perhatian }\end{array}$ & $\begin{array}{l}\text { Pemprov DKI menanggapi keluhan } \\
\text { masyarakat }\end{array}$ & 17, & 5 \\
& $\begin{array}{l}\text { - Kepedulian petugas PPB } \\
\text { Kemudahan masyarakat dalam } \\
\text { berkomunikasi kepada petugas } \\
\text { Pemprov DKI tidak menyusahkan } \\
\text { masyarakat }\end{array}$ & $19, \quad 20$, & \\
\hline
\end{tabular}


Tabel 5

Kisi-kisi Instrumen Penelitian Tangible Kualitas Pelayanan

\begin{tabular}{|l|l|l|c|}
\hline \multicolumn{1}{|c|}{ Variabel } & \multicolumn{1}{|c|}{ Indikator } & \multicolumn{1}{c|}{ No Item } & Jumlah \\
\hline $\begin{array}{l}\text { Tangible/Bukti } \\
\text { Fisik }\end{array}$ & $\begin{array}{l}\text { - Fasilitas sarana dan prasarana } \\
\text { yang digunakan termasuk baik dan } \\
\text { lengkap } \\
\text { - Kualitas barang maupun kemasan } \\
\text { dalam keadaan baik }\end{array}$ & 22,24, & \\
& - Ketersediaan dan kesesuaian \\
& penempatan kerja pada petugas \\
& terhadap pelayanan PPB & 23 & \\
\end{tabular}

Tabel 5

Kisi-kisi Instrumen Penelitian Kepuasan Masyarakat

\begin{tabular}{|l|l|l|c|}
\hline \multicolumn{1}{|c|}{ Variabel } & \multicolumn{1}{|c|}{ Indikator } & No Item & Jumlah \\
\hline Kepuasan & $\begin{array}{l}\text { - Kualitas Pangan Bersubsidi } \\
\text { berkualitas baik } \\
\text { - Harga Pangan Bersubsidi sesuai } \\
\text { kulaitas pangan } \\
\text { - Jangka waktu mengkonsumsi } \\
\quad \text { Pangan Bersubsidi }\end{array}$ & 1,5, & 14 \\
& $\begin{array}{l}\text { Memperoleh banyak manfaat } \\
\text { Pangan Bersubsidi } \\
\text { Terdapat penukaran pangan } \\
\text { Tanggap atas sikap protes } \\
\text { masyarakat }\end{array}$ & 3, & \\
& 6, & \\
& 7, & \\
\hline
\end{tabular}




\begin{tabular}{|c|c|c|}
\hline & $\begin{array}{l}\text { - Informasi pelayanan yang akurat } \\
\text { - Adanya solusi kepada masyarakat } \\
\text { - Sikap mengalami masalah pangan } \\
\text { transaksi } \\
\text { - Lokasi penjualan dapat dipercaya } \\
\text { - Akses pembelian Pogram Pangan } \\
\text { Bersubsidi } \\
\text { - Mampu mewujudkan permintaan } \\
\text { sesuai selera masyarakat saat } \\
\text { melakukan transaksi } \\
\text { - Penetapan harga pangan sesuai } \\
\text { prosedur }\end{array}$ & $\begin{array}{l}9, \\
8, \\
10, \\
12, \\
11, \\
13, \\
14\end{array}$ \\
\hline
\end{tabular}

\section{Pengujian Instrumen Penelitian}

Uji validitas instrumen tangible (bukti fisik) pada kualitas pelayanan terdapat 1 butir soal yang gugur sedangkan instrumen kepuasan masyarakat tidak ada butir soal yang gugur. Uji Reliabilitas instrumen untuk variabel kualitas pelayanan sebesar 0,961 dan variabel kepuasan masyarakat sebesar 0,926. Besarnya nilai reliabilitas lebih besar dari alpha minimum yaitu $(\alpha=0,50)$, maka dapat disimpulkan bahwa instrumen kualitas pelayanan dan kepuasan masyarakat tersebut reliabel.

\section{Teknik Analisis Data:}

Analisis Regresi Linear Berganda. Analisis regresi linear berganda ini digunakan untuk mengetahui seberapa besar pengaruh pada variabel bebas yaitu Reliability, Responsiveness, Assurance, Empathy, dan Tangible terhadap variabel terikat yaitu kepuasan masyarakat.

Koefisien Determinasi. Koefisien Determinasi $\left(\mathrm{R}^{2}\right)$ ini digunakan untuk mengukur seberapa besar kontribusi variabel bebas terhadap variabel terikat. Apabila Koefisien Determinasi (R2) ini semakin besar atau mendekati angka satu, berarti dapat menunjukkan semakin baiknya kemampuan variabel $\mathrm{X}$ menerangkan variabel $Y$, di mana $0<\mathrm{R} 2<1$. Dan sebaliknya, jika R2 semakin kecil atau mendekati angka nol, maka akan dapat dikatakan bahwa bentuk pengaruh yang diberikan variabel bebas adalah kecil terhadap variabel terikatnya. 


\section{Hasil dan Diskusi}

\section{Deskripsi Hasil Penelitian}

Penelitian ini dilakukan di RPTRA Pinang Pola dan RPTRA Pola Idaman di Kelurahan Pondok Labu, Jakarta Selatan. Subyek penelitian adalah masyarakat yang mendapatkan pangan bersubsidi dengan menggunakan kartu Jakarta Pintar. Waktu pelaksanaan penelitian dilakukan pada bulan Maret 2019.

Pengujian Persyaratan Analisis: 1) Uji Normalitas. Berdasarkan hasil Uji Kolmogorov-Smirnov Test maka diperoleh nilai seluruhnya yaitu 0,001. Penelitian ini dapat dikatakan berdistribusi normal, karena setiap variabel memiliki probabilitas (p) $>0,05 ; 2$ ) Uji Homogenitas, Uji homogenitas adalah merupakan uji perbedaan antara dua atau lebih populasi yang mana mempunyai tujuan untuk mengetahui apakah skor yang diukur pada kedua sampel memiliki varian yang berbeda atau tidak sama sekali. Maka dari itu, keseluruhan nilai homogenitas lebih kecil dari nilai alpha 0,05. Penjelasannya ialah, reliability $0,001<0,05$, responsiveness $0,026<0,05$, assurance $0,022<0,05$, empathy 0,003 $<0,05$ dan tangible $0,007<0,05$ maka hasil dari nilai di atas ialah data tersebut bersifat homogen.

3) Uji Multikolineritas, Uji Multikolinearitas dilakukan untuk mengetahui ada atau tidaknya hubungan linier yang sempurna atau pasti, di antara beberapa atau semua variabel yang menjelaskan dari model regresi. Hasil uji multikolineritas data menunjukkan bahwa dari masing-masing variabel bebas yang signifikan dilihat pada nilai VIF tidak adanya nilai yang lebih dari nilai 10 dan lebih kecil dari 0,10 pada tolerance, maka dapat disimpulkan bahwa tidak terjadinya multikolineritas.

\section{Pembahasan Hasil Penelitian,}

Hasil analisis dari penelitian menyatakan bahwa terdapat pengaruh yang positif dan signifikan antara variabel bebas yaitu Reliability (X1), Responsiveness (X2),Assurance (X3),Empathy (X4), dan Tangible (X5) terhadapvariabelkepuasan masyarakat $(\mathrm{Y})$ yang dapat dilihat dari taraf signifikansi $\mathrm{F}<$ signifikansi $5 \%$ $(0,000<0,05)$. Hal ini berarti $\mathrm{H}_{1}$ diterima dan $\mathrm{H}_{0}$ ditolak yaitu dapat dibuktikan bahwa terdapat pengaruh yang positif dan signifikan antara variabel kualitas pelayanan terhadap variabel kepuasan masyarakat. Pada besaran nilai koefisen determinasi atau $\mathrm{R}^{2}$ (R Square) adalah sebesar 0,596. Untuk itu, berarti variabel Reliability (X1), variabel Responsiveness (X2), variabel Assurance (X3), variabel 


\section{Pengaruh Kualitas Pelayanan Program Pangan Bersubsidi terhadap Kepuasan}

Masyarakat di Kelurahan Pondok Labu Jakarta Selatan

- Puteri Nur Farrieda

Empathy (X4) dan variabel Tangible (X5) mempengaruhi pada variabel Kepuasan Masyarakat (Y) sebesar 59,6\%. Sedangkan sisanya senilai 40,4\% dipengaruhi ataupun dijelaskan oleh variabel lain di luar dari variabel penelitian, seperti memberikan senyum, salam dan sapa.

\section{Kesimpulan}

Kesimpulan yang dapat diambil dari penelitian kali ini berdasarkan uji parsialnya variabel reliability (X1), assurance (X3) dan tangible (X5) terdapat pengaruh terhadap kepuasan masyarakat dengan signifikan masing-masing sebesar 0,002, 0,046 dan 0,000. Sedangkan pada variabel responsiveness (X2) dan empathy (X4) tidak berpengaruh terhadap kepuasan masyarakat dengan nilai signifikannya 0,826 dan 0,891. Adapun penjelasan berdasarkan hasil analisis koefisien korelasi, antara variabel kualitas pelayanan (X) dengan variabel kepuasan masyarakat (Y) adalah memiliki nilai 0,772 yang dapat dikategorikan memiliki hubungan yang kuat.

Kualitas pelayanan secara serentak berpengaruh positif dan signifikan dengan nilai 59,6\% terhadap kepuasan masyarakat dalam Program Pangan Bersubsidi. Tetapi untuk sisanya senilai $40,4 \%$ berada pada variabel lain di luar dari variabel reliability, responsiveness, assurance, empathy dan tangible.

\section{Daftar Pustaka}

Badan Pusat Statistik DKI. (2018). DKI Dalam Angka 2018. BPS DKI. DIakses dari https://jakarta.bps.go.id/ publication/2018/08/16/67d90391b7996f51d1c625c4/provinsi-dkijakarta-dalam-angka-2018.html

Zuraya, N. (2019, 20 September). Bank Dunia: Tingkat Kemiskinan Global Turun. MSN.com. Diakses dari https://www.msn.com/id-id/ekonomi/ ekonomi/bank-dunia-tingkat-kemiskinan-global-turun/ar-BBNA44E

Supriyatna, T. (1997). Birokrasi, Pemberdayaan, dan Pengentasan Kemiskinan. Bandung: Humaniora Utama Press.

Singarimbun, M., dan Effendi, S. (2008). Metode Penelitian Survei. Jakarta: LP3ES. Fedryansyah, M. (2016). Kebijakan Sosial Dalam Pembangunan. Social Work Journal.

Purwaningsih, Y. (2008). Ketahanan Pangan: Situasi, Permasalahan, Kebijakan, dan Pemberdayaan Masyarakat. Jurnal Ekonomi Pembangunan. 
Rezha, F., Rochmah, S., \& Siswidiyanto. (2013). Analisis Pengaruh Kualitas Pelayanan Publik Terhadap Kepuasan Masyarakat (Studi Tentang Pelayanan Perekaman Kartu Tanda Penduduk Elektronik (e-KTP)). Jurusan Administrasi Publik, Universitas Brawijaya Malang.

Statistika, B. P. (1997). Statistika Kesejahteraan Rumah Tangga. Jakarta: BPS.

Sugiyono. (2009). Penelitian Kuantitatif Kualitatif dan R\&D. Bandung: Alfabeta. 